Institute of $\mathbf{F}_{\text {ood and }} \mathbf{A}_{\text {gricultural }} \mathbf{S}_{\text {ciences }}$

\title{
Cigarette Beetle, Lasioderma serricorne (F.) (Insecta: Coleoptera: Anobiidae) ${ }^{1}$
}

Brian J. Cabrera ${ }^{2}$

\section{Introduction}

There are over 1000 described species of anobiids. Many are wood borers but two, the cigarette beetle, Lasioderma serricorne (F.), also known as the tobacco beetle, and the drugstore beetle, Stegobium paniceum (L.) are pests of stored products. Stored-product pests are responsible for tremendous damage and economic losses to post-harvest and stored grains and seeds, packaged food products, and animal and plant derived items and commodities. Besides causing direct damage by their feeding, they also elicit disgust, annoyance, and anger in those who find them infesting these products. The cigarette beetle is a commonly encountered stored-product pest in the home and has long been associated with humans -- some were found in dried resin from the tomb of Egyptian King Tutankhamun.

\section{Distribution}

The cigarette beetle is pan-tropical but can be found worldwide -- especially wherever dried tobacco in the form of leaves, cigars, cigarettes, or chewing tobacco is stored.

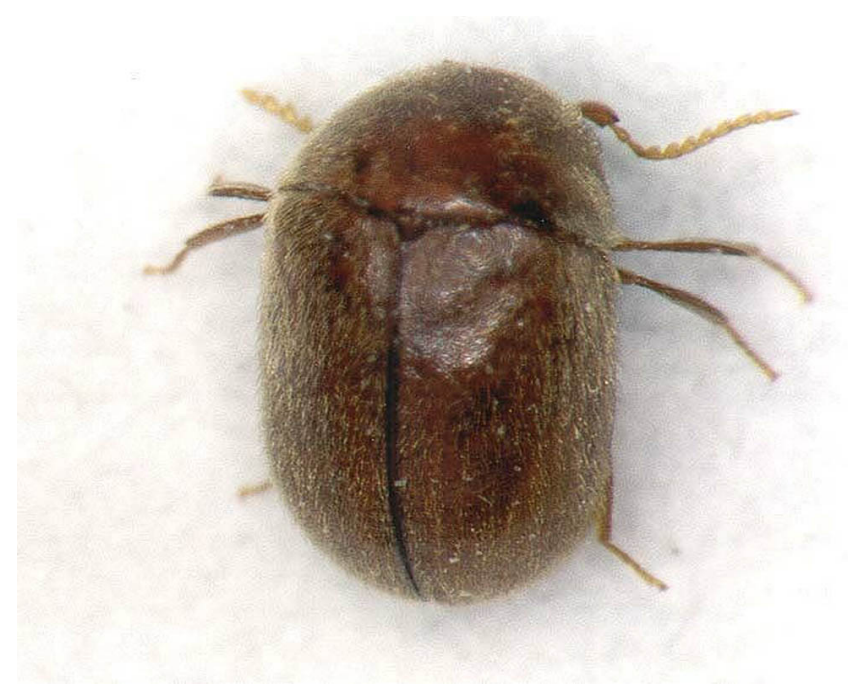

Figure 1. Adult cigarette beetle, Lasioderma serricorne (F.). Credits: B.J. Cabrera, University of Florida

\section{Description and Identification}

\section{Adults}

Cigarette beetles are quite small, measuring about 2 to $3 \mathrm{~mm}$ (about 1/8 of an inch), and are reddish brown. They have a rounded, oval shape and the head is often concealed by the pronotum when the beetle is viewed from above. The elytra (wing covers) are covered with fine hairs. When disturbed

1. This document is EENY-227, one of a series of Featured Creatures from the Entomology and Nematology Department, Florida Cooperative Extension Service, Institute of Food and Agricultural Sciences, University of Florida. Published: July 2001. This document is also available on Featured Creatures Website at http://creatures.ifas.ufl.edu. Please visit the EDIS Website at http://edis.ifas.ufl.edu. Additional information on these organisms, including many color photographs, is available at the Entomology and Nematology Department website at http://entnemdept.ifas.ufl.edu/.

2. Brian J. Cabrera, assistant professor, Entomology and Nematology Department, Ft. Lauderdale REC, University of Florida, Ft. Lauderdale, FL 33314.

The Institute of Food and Agricultural Sciences is an equal opportunity/affirmative action employer authorized to provide research, educational information and other services only to individuals and institutions that function without regard to race, color, sex, age, handicap, or national origin. For information on obtaining other extension publications, contact your county Cooperative Extension Service office. Florida Cooperative Extension Service/Institute of Food and Agricultural Sciences/University of Florida/Christine Taylor Waddill, Dean. 
they often pull in their legs, tuck their head and lay motionless. They prefer to reside in dark or dimly lit cracks, nooks and crevices but become active and fly readily in bright, open areas, probably in an attempt to find refuge. They are most active at dusk and will continue activity through the night. Adults do not feed but will drink liquids. Cigarette beetles look almost identical to drugstore beetles but can be distinguished by two easily identifiable characters: the antennae of the cigarette beetle are serrated (like the teeth on a saw) while the antennae of the drugstore beetle are not and end in a 3-segmented club. The other difference is that drugstore beetle elytra have rows of pits giving them a striated (lined) appearance while those of the cigarette beetle are smooth.

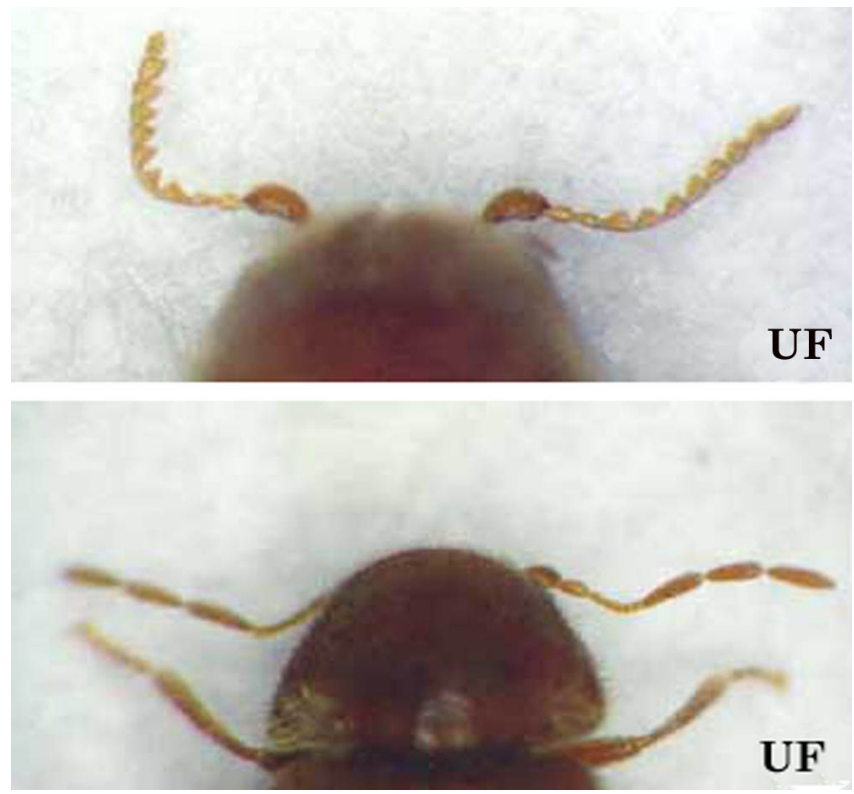

Figure 2. Serrated antennae of a cigarette beetle, Lasioderma serricorne (F.), (top); and clubbed antennae of a drugstore beetle, Stegobium paniceum (L.) (bottom). Credits: B.J. Cabrera, University of Florida

\section{Larvae}

Older larvae are white, scarab-like, and hairy. They are similar to drugstore beetle larvae but the hair is longer, the head is evenly rounded dorsally and has a dark marking with a convex boundary that extends halfway up the frons. An arolium is also present and extends beyond the middle of the claw on each tarsus.

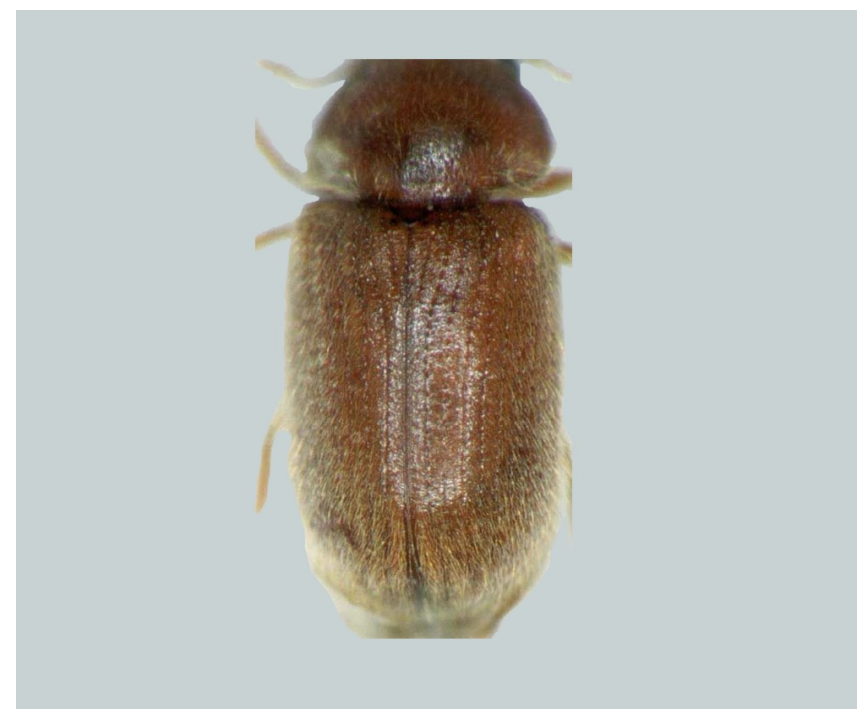

Figure 3. Striated elytra of an adult drugstore beetle, Stegobium paniceum (L.). Credits: B.J. Cabrera, University of Florida

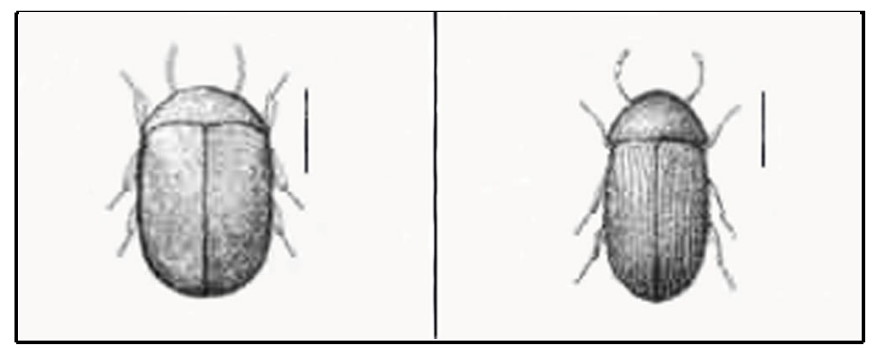

Figure 4. Comparison of the elytra and antennae of the cigarette beetle, Lasioderma serricorne (F.), (left); and drugstore beetle, Stegobium paniceum (L.) (right). Credits: Division of Plant Industry

\section{Life History}

The length of the cigarette beetle life cycle is highly dependent on temperature and the food source but usually takes 40 to 90 days. Females lay 10 to 100 eggs in the food and the larvae emerge in six to 10 days. After feeding for five to 10 weeks, during which they go through four to six instars, the larvae excavate a protective cell in the feeding substrate or build a protective cocoon from bits of food and debris. Pupation takes from one to three weeks and after emerging the adults live from one to four weeks. In warmer climates there may be five or six overlapping generations. Development periods of 26 days at $37^{\circ} \mathrm{C}$ and 120 days at $20^{\circ} \mathrm{C}$ have been reported. Development is incomplete at $17^{\circ} \mathrm{C}$ and adults die when exposed to $4^{\circ} \mathrm{C}$ for six days. 


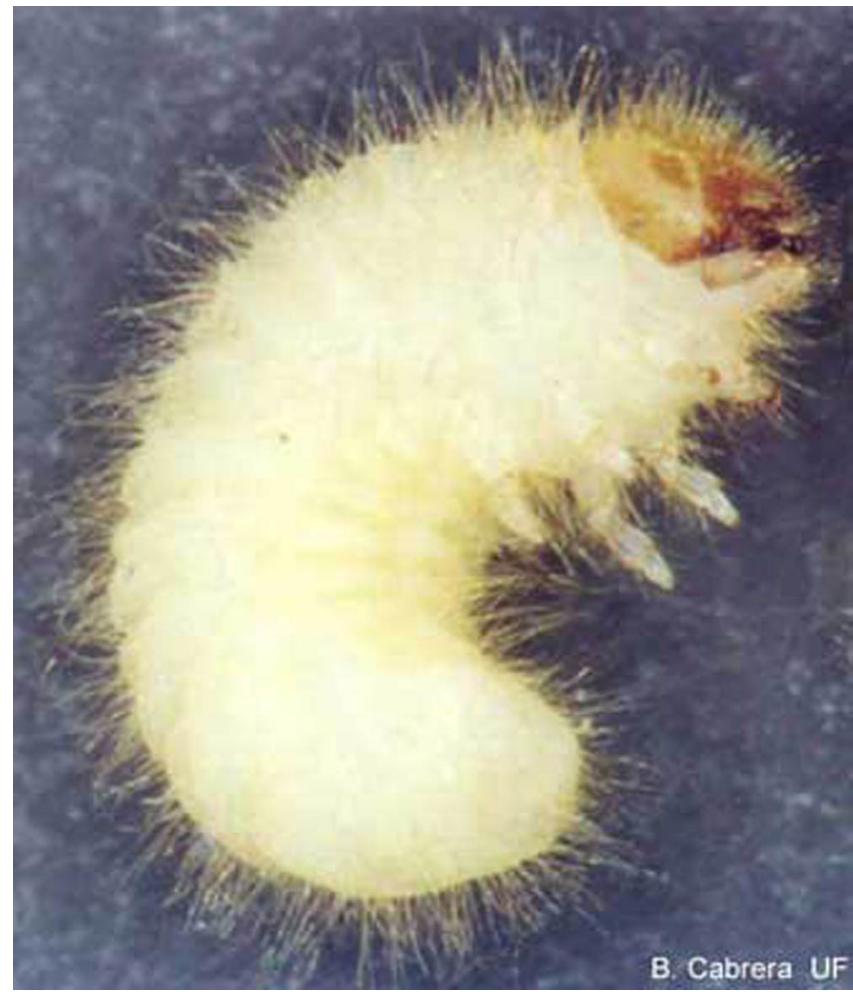

Figure 5. Larva of the cigarette beetle, Lasioderma serricorne (F.). Credits: B.J. Cabrera, University of Florida

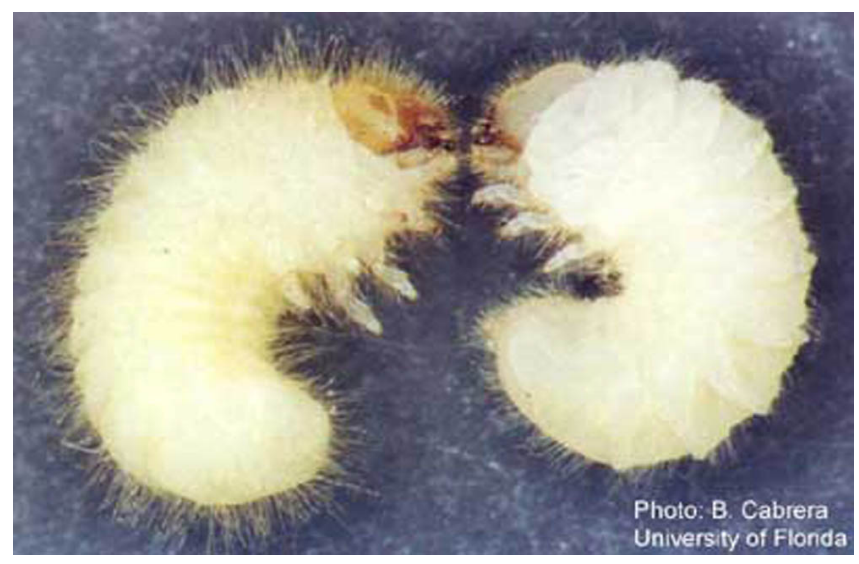

Figure 6. Comparison of a larva of a cigarette beetle, Lasioderma serricorne (F.), (left); and the drugstore beetle, Stegobium paniceum (L.) (right). Credits: B.J. Cabrera, University of Florida

\section{Pest Status}

Besides the dubious honor of being the most damaging pest of stored tobacco, the cigarette beetle also is a major pest of many stored food products including flours, dry mixes, dried fruits such as dates and raisins, cereals, cocoa, coffee beans, herbs, spices, nuts, rice, dry dog food and other products kept in kitchen cabinets, pantries and other areas in the home. Non-food products that it infests include dried plants and herbarium specimens, dried floral arrangements, potpourri, decorative grapevine wreaths, prescription drugs and pills, medicinal herbs, pinned insects, furniture stuffing, papier-mâché, and bookbinding paste. Cigarette beetles harbor symbiotic yeasts that produce B vitamins. The yeasts are deposited on the eggs as they pass through the oviduct and are consumed by the larvae during egg hatch. These yeasts enable the cigarette beetle to feed and survive on many foods and other items of poor nutritional quality. The drugstore beetle also has symbiotic yeasts but they are of a completely different species.

\section{Damage}

Larval feeding causes direct damage to foodstuffs and non-food items. These products are contaminated by the presence of beetles, larvae, pupae, cocoons, frass (fecal material), and insect parts. Beetles chewing through cardboard boxes and containers, and packaging cause indirect damage. Cocoons are often attached to a solid substrate and in severe infestations form large clusters. Larvae will sometimes bore their way through cardboard boxes and other packaging in search of a place to pupate.

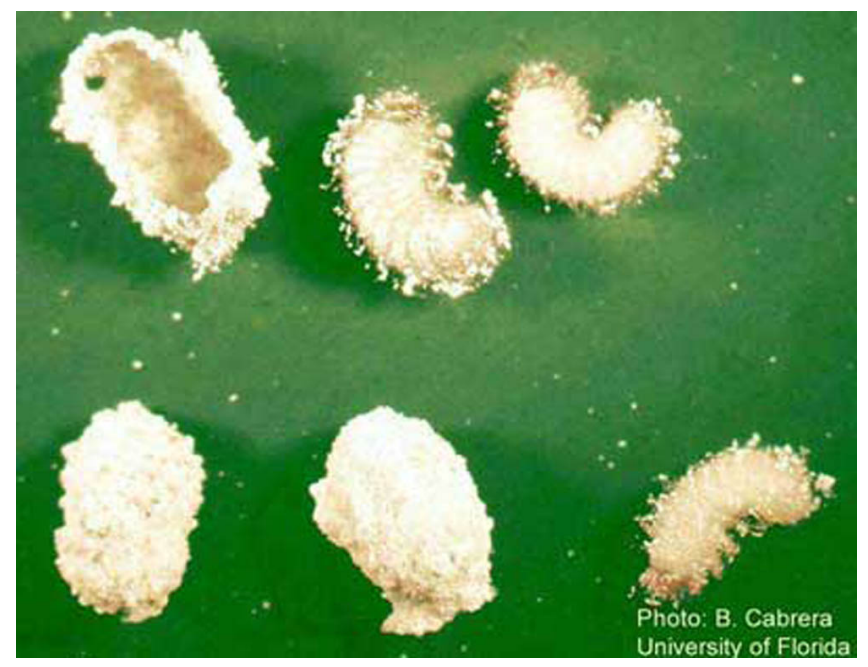

Figure 7. Larvae and cocoons of the cigarette beetle, Lasioderma serricorne (F.). Credits: B.J. Cabrera, University of Florida 


\section{Management}

\section{Home}

Preventing and controlling cigarette beetle infestations in the home is relatively simple; insecticides should be used only as a last resort. Locating the source of infestation is the first and most important step. Heavily infested items should be wrapped in heavy plastic, taken outside and thrown away. All food containers and items should be checked for infestation. Items can be placed in the refrigerator or freezer ( 16 days at $36^{\circ} \mathrm{F}, 7$ days at $25^{\circ} \mathrm{F}$ or $32^{\circ} \mathrm{F}$ for four to seven days) to kill all stages. Place items in a plastic bag to reduce condensation problems during thawing. Heating small quantities of infested material in an oven $\left(190^{\circ} \mathrm{F}\right.$ for one hour, $120^{\circ} \mathrm{F}$ for 16 to 24 hours) also is effective. Uninfested items can be cold- or heat-treated to ensure that any undetected infestations are killed. To prevent reinfestation, clean up spilled flour, mixes, crumbs, etc. and thoroughly vacuum and clean areas where the contaminated items were stored. Store foods in airtight glass, metal or plastic containers. Clear containers make it easier to check for infestations. Chemical treatment using commercially available insecticides is usually not necessary. There are several insecticides and insect growth regulators labeled for use on cigarette beetles. Always be sure to read and follow the label.

See the Insect Management Guide for Pantry and Stored Food Pests (http://edis.ifas.ufl.edu/IG095) for current management recommendations.

\section{Commercial}

The cigarette beetle is a frequent pest in flour mills, bakeries, pet food, breakfast cereal manufacturing, and snack food plants, chocolate factories, confectionaries, wholesale distribution centers and sometimes retail stores. Integrated pest management (IPM) programs are often implemented to control infestations at processing, distribution, and storage facilities.

Large-scale control for severe infestations can be achieved by fumigating. However, the use of one fumigant, methyl bromide -- which destroys ozone in the atmosphere -- will be banned in 2005 according to an addition to the Montreal Protocol (an international agreement signed by over 150 countries) in 1995 . Large-scale heat treatment has been used with limited success. A temperature of approximately $50^{\circ} \mathrm{C}$ $\left(122^{\circ} \mathrm{F}\right)$ maintained for 24 to 36 hours is needed for effective control.

Residual insecticides registered for use on cigarette beetles can be applied to cracks, crevices and shelves in storage areas after removal of stored products (check labels for specific use). Insect growth regulators (IGR) also are used as part of an IPM program. The use of methoprene on stored tobacco was one of the first uses of an IGR on a stored commodity. Sticky traps baited with the female cigarette beetle sex pheromone, serricornin, can be used to monitor for beetles. Mass-trapping -- which involves setting out large numbers of traps in infested areas with the intent of catching large numbers of beetles to reduce the population -- has been tried but effectiveness is limited because only males are attracted to the traps. For mass trapping of cigarette beetles to succeed, a large enough number of males must be caught to ensure that few females will be mated. Some claims of successful population reduction have been made with this method but pheromone traps are mostly used for detecting and monitoring beetle populations. The traps typically are set out in a grid-like pattern within a facility and monitored at regular intervals for trapped males. If one or more traps in a particular area happen to catch a greater proportion of beetles, then more traps are set out in that area to pinpoint the source of infestation.

See the Insect Management Guide for Pantry and Stored Food Pests (http://edis.ifas.ufl.edu/IG095) or Stored Grain Pests (http://edis.ifas.ufl.edu/IG103) for current management recommendations.

\section{Natural Enemies}

Cigarette beetle predators include Tenebriodes (Tenebrionidae), Thaneroclerus (Cleridae) and several carabids. Eggs may be eaten by predatory mites. Parasitoids include wasps in the families Pteromalidae, Eurytomidae and Bethylidae. Biological control for stored-product pests, however, has not been widely adopted. Part of the problem is that although it reduces the amount of pesticides used 
for control, the release of insects to control cigarette beetles increases contamination of foodstuffs with potentially more insects and insect parts.

\section{Chemical Ecology}

Female sex pheromone is vital to cigarette beetle mating success. Laboratory assays in one study determined that the active fraction of female extract that elicited the most activity in males is serricornin (4,6-dimethyl-7-hydroxy-nonan-3-one). Detection of this compound by males elicited mating behaviors such as antennal elevation with leg extension and rapid locomotion to the pheromone source. Synthetic serricornin is used in commercially available cigarette beetle traps although, depending on the manufacturer, there is variation in the chemical and isomeric purity of the synthetic compound.

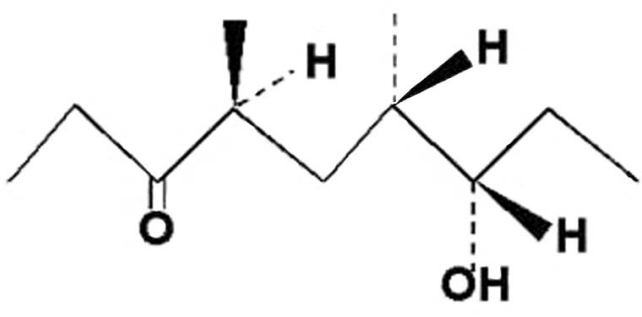

Serricornin

\section{$U F$}

Figure 8. Chemical structure of serricornin, the sex pheromone of the cigarette beetle, Lasioderma serricorne (F.). Credits: B.J. Cabrera, University of Florida

\section{Selected References}

Baur, F. J. 1991. Chemical methods to control insect pests of processed foods. pp. 427-440. In J. R. Gorham (ed.), Ecology and Management of Food-Industry Pests. FDA Technical Bulletin 4.

Chuman, T., K. Mochizuki, M. Mori, M. Kohno, K. Kato, and M. Noguchi. 1985. Lasioderma chemistry, Sex pheromone of cigarette beetle (Lasioderma serricorne F.). Journal of Chemical Ecology 11:417-434.

Granovsky, T. A. Stored product pests. pp. 635-728. In D. Moreland (ed.), Handbook of Pest Control (by A. Mallis), Eighth Edition. Mallis Handbook and Technical Training Co.
Hill, D. S. 1990. Pests of stored products and their control. CRC Press, Boca Raton. 274 pp.

Howe, R. W. 1957. A laboratory study of the cigarette beetle, Lasioderma serricorne (F.)(Col., Anobiidae) with a critical review of the literature on its biology. Bulletin of Entomological Research 48:9-56.

Krischik, V. and W. Burkholder. 1995. Stored-product insects and biological control agents. pp. 85-102. In Krischik, V., G. Cuperus, and D. Galiart (eds.) Stored product management. Oklahoma Cooperative Extension Service Circular Number E-912.

Phillips, T. W. 1994. Pheromones of stored-product insects: current status and future perspectives. pp. 479-486. In E. Highley, E. J. Wright, H. J. Banks and B. R. Champ (eds.), Proceedings of the 6th International Working Conference on Stored-product Protection, Vol. 1. CAB International, Wallingford, U.K.

Phillips, T.W., R. C. Berberet, and G. W. Cuperus. 2000. Postharvest integrated pest management, pp. 2690-2701. In F. J. Francis (ed.), The Wiley Encyclopedia of Food Science Technology, 2nd Edition. John Wiley and Sons, New York.

Phillips, T. W., P. M. Cogan, and H. Y. Fadamiro. 2000. Pheromones, pp. 273-302. In B. Subramanyam \& D. W. Hagstrum (eds.), Alternatives to pesticides in stored-product IPM. Kluwer Academic Publishers, Boston.

United States Department of Agriculture. 1980. Stored-grain insects. USDA-ARS Agriculture Handbook Number 500, 57 pp. 